\title{
THE RHETORICAL STRUCTURE OF JOHN CHRYSOSTOM'S SEVENTH HOMILY ON PHILIPPIANS IN RELATION TO THE KENOSIS HYMN
}

ABSTRACT: The purpose of this study is a description the rhetorical structure of John Chrysostom's seventh homily on Philippians in relation to the kenosis hymn. The analysis aims to identify and characterize individual structures within the homily. This is done with a view to highlighting the delibrate usage of rhetorical argument as an instrument for biblical text analysis in the construction of Chrysostom's sermon. The study includes two sections. The first one is a theoretical introduction to St. John's style, followed by investigation into the origin of the homily. The subject matter of Chrysostom's work is also discussed. The second part of the article is a thorough description of the structure of John's text. The chapter is a detailed and systematic analysis of elements showcasing the author's rhetorical skills.

KEY WORDS: John Chrysostom, homily, rhetoric, biblical hermeneutics, Church Fathers

John Chrysostom ${ }^{1}$ received an excellent education in the field of rhetoric from his master Libanios, whom he followed as an ardent disciple. He

\footnotetext{
Standard works on Chrysostom are: Baur 1959-1960; Kelly 1995; Mayer, Allen 2000. There is a comprehensive online bibliography recalled by $\mathrm{P}$. Allen in aforementioned work and prepared by W. Mayer available at: http://www.cecs.acu.edu.au/ chrysostombibliography.htm.
} 
became known primarily for his sermons, which in themselves are works inherently designed to be delivered orally, giving the speaker an excellent opportunity to prove his skill. Maintaining the basic premise, which is to provide a commentary on a particular part of the Bible, his homily is also an example of oration, which fulfills the fundamental guidelines of rhetoric based on ancient theory. The main purpose of this study is a structural and textual analysis of John Chrysostom's seventh homily in relation to the Letter of Paul to the Philippians, with particular regard to the specifics of ancient rhetorical texts. The analysis will be based on the assumption that the homily displays a two-phase structure, featuring inventio, i.e. the invention of content as a means to develop an effective argument, and dispositio, which refers to the method of organizing the content.

By the end of the $4^{\text {th }}$ century, Chrysostom began his systematic exegesis of the Letters of Saint Paul, delivering a series of speeches inspired by them. It seems that the earliest among these, published already by late spring $399 \mathrm{AD}$, were his fifteen homilies based on the Letter to the Philippians. One of the most recent and inclusive collections of translations of Chrysostom's homilies on Philippians, ${ }^{2}$ although it does not undermine the fact that the homilies are the first recorded attempts at explaining Saint Paul's Letters, calls into question whether or not John the Golden Mouth completed the homilies one after another and whether he did so within a single time frame. ${ }^{3}$ One of the studies of Chrysostom's homilies on Colossians suggests that they were written episodically over a longer period, at various times during his residence first in Antioch and then in Constantinople. ${ }^{4}$ One argument that is invoked to support such a claim is the lack of consistency in content between indvidual texts in the cycle: few of them are related to each other by a coherent line of reasoning. ${ }^{5}$ Furthermore, there are clear differences

\footnotetext{
2 Allen 2013. P. Allen's work stands out among the relatively small number of translations of Chrysostom's homilies and includes all fifteen sermons under discussion, with an extensive general introduction and annotations accompanying each text. Other translations are: into French by Bareille (1872); into English by Cotton (1843); and into German by Stoderl (1924).

Allen 2013: XII.

Allen, Mayer 1995: 274-275.

Bady 2010: 149-163; Allen, Mayer 1995: 270-289.
} 
in style, considered otherwise unrefined, between the individual homilies in the cycle. Attempts to date the speeches under discussion may be based on references to the contemporary socio-political situation and the digressions he makes regarding the exercise of power. An example of this may be found in a homily in which the Golden Mouth refers to the contemporaneous despotic reign of Eutropios and the collapse of his imperial house. ${ }^{6}$ Nevertheless, any attempt to give a date to the homilies is difficult and remains disputable.

Although many scholars have discussed the style of Chrysostom's works, ${ }^{7}$ the investigation into the rhetorical structure of each homily has clearly not been a priority. And yet this kind of analysis could reveal how relevant the rhetorical devices are to the appropriate understanding of the content of the homilies and also could demonstrate the artful, fluent and effortless skill in the application of these types of stylistic figures by the Antiochian Bishop. The criteria of the following description are based on the rules of rhetoric, collected by $\mathrm{H}$. Lausberg in his monumental work, Handbook of Literary Rhetoric, ${ }^{8}$ that concern the particular kind of speech we are interested in.

Turning our attention to Chrysostom's seventh homily on Philippians let us first specify its main topic and aim, which will consequently simplify its classification as to the kind of speech it represents. Taking into account the fundamental goal of the homily, it seems appropriate to consider it a representative of the deliberative genre. The main assumption of the genus deliberativum is to recommend some course of action which is relevant to the audience's future and could influence history. ${ }^{9}$ In accordance with this, the following elements may be distinguished in the homily under discussion:

- The author wants to persuade the audience to preserve a humble attitude, warns them against avarice and indicates the ineptness of heresies of their times, convincing listeners ipso facto to accept the orthodox catholic faith - the speech is therefore of an advisory nature;

- Chrysostom's words have future relevance - the Church Father wants the audience to adopt his advice;

\footnotetext{
$6 \quad$ Kelly 1995: 146.

$7 \quad$ Cf. Amirav 2004; Cunningham, Allen 1998; Illert 2000; Mitchell 2002.

$8 \quad$ Lausberg 1998.

$9 \quad$ Lausberg 1998: 97.
} 
- The speaker's recommendations are meant to influence the morality of the listeners, and consequently improve the condition of the Church;

- The orator uses specific language forms typical of the deliberative genre, especially verbs in the imperative, such as $\pi \rho \sigma \sigma \varepsilon \dot{\chi} \chi \tau \varepsilon$, $\delta \iota \alpha v \alpha ́ \sigma \tau \eta \tau \varepsilon$, and $\kappa \alpha \tau \varepsilon \pi \alpha \dot{\alpha} \delta \varepsilon \tau \varepsilon$.

Not all elements of the speech can be described in terms of the characteristics of deliberative speech. Nonetheless, if we find some of the basic qualities of this genre in the text, this will give us the opportunity to deal with this issue. It is clear that Chrysostom was not fettered by the principles of deliberative rheoric. On the contrary, they allowed him to compose a clear and succinct speech.

\section{INVENTIO}

\subsection{Exordium et narratio}

Taking into account the object of the homily, classified with the genus honestum (moral case), it is possible to accept that Chrysostom begins his speech with a prooemium. In contrast to the exordium insinuatio, the prooemium is the neutral form of introduction, the sole purpose of which is to prepare the audience to listen to the entire content. According to the principles of rhetoric, this could be achieved by the following methods: iudicem benevolum parare, iudicem docilem parare and iudicem attentum parare. ${ }^{10}$ Taking into account that the speaker is well known to his listeners, exordium does not contain any distinct example of iudicem benevolum, yet the special phrase 'Our Lord' is remarkable, as it appears at the beginning, where the preacher turns to the community and highlights his special affection for the audience. In his willingness to attract the attention of all listeners, Chrysostom looks for vocabulary that could underline the significance of the matter. He employs emotionally charged phrases, the purpose of which is to elicit fear (metus): mostly imperative forms of verbs such as awake, watch out etc.

A structure can be found in the initial part of the homily which discusses the manner in which Jesus and Saint Paul encouraged their

$10 \quad$ Lausberg 1998: 121-132. 
audiences to be humble. In this way, Chrysostom underlines the primary theme of the whole speech, which is insistence on humility. The structure of this encouragement is both considerate and clear, expressed by means of parallel constructions:

\section{Structure [1]:}

a) Jesus Christ urged his disciples to be humble by giving himself and his Father as an example:

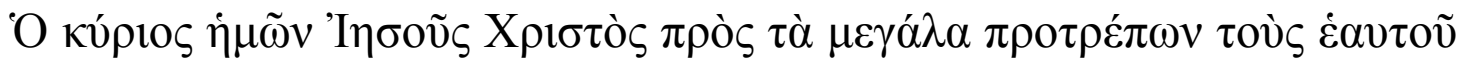

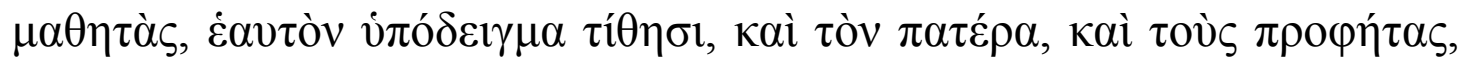
$\omega \varsigma$ ö $\tau \alpha \nu \lambda \varepsilon \dot{\varepsilon} \gamma \eta^{\cdot 11}$

b) Saint Paul advocated humility by giving Jesus Christ as an example:

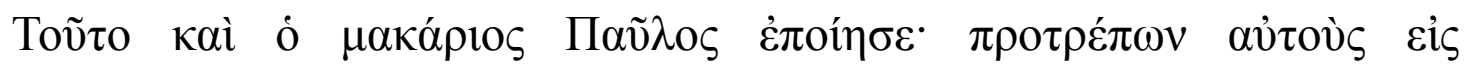

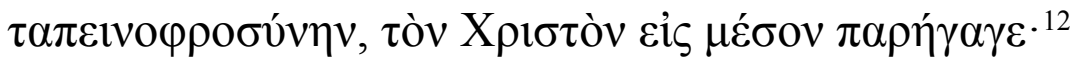

In view of this structure, however, the first difficulty appears when attempting to identify the particular elements of ancient speeches. This is because the presentation of the topics which the speaker deals with throughout the speech is characteristic of the second part, the narratio. In this homily, nonetheless, it is impossible to indicate exactly where the exordium finishes and the narratio begins. It appears that the two overlap. The preliminary description of the case seems to be consistent with the features of the narratio brevis, maintaining the basic principle of presenting the case in a brief, concise and clear way. ${ }^{13}$ Afterwards, Chrysostom uses two metaphors, which could be more precisely characterised as an element of narration referred to as digressio in rhetoric. ${ }^{14}$ The first one taken from the Scripture, compares the words of the Holy

11 Greek text: Migne 1862: 218-228, here: 221. English translation according to: Allen 2013: 113-169, here: 113. [Our Lord Jesus Christ, while exhorting his disciples to great deeds, makes an example of himself and his Father, and the prophets, as when he says:].

$12 \quad$ PG 62: 113; Allen 2013: 113. [Blessed Paul did this too - by exhorting them to humility, he brought Christ].

13 Lausberg 1998: 141.

$14 \quad$ Lausberg 1998: 158. 
Spirit to a two-edged sword, and the second one presents a racing chariot whose rider overcomes all the oponents, just as the words of the Holy Bible disprove all heresies. What is remarkable, the speaker repeats the second simile in the passage that follows. This image therefore creates a kind of bridge linking the subject matter of the homily with the issue of the heresies.

\section{Digressio [metaphors]:}

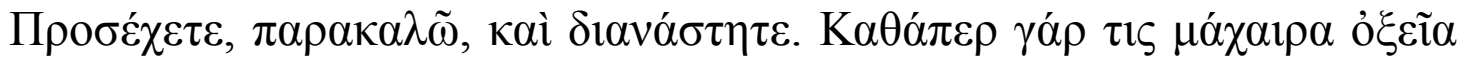

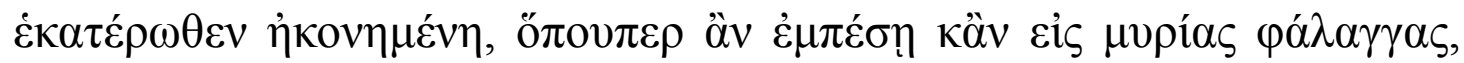

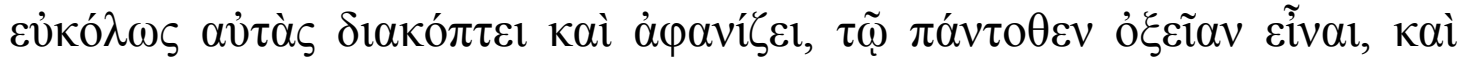

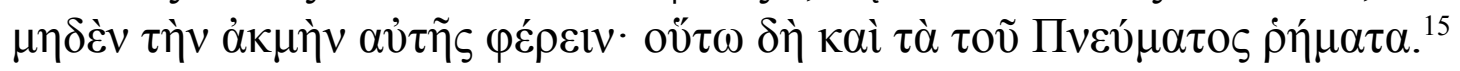

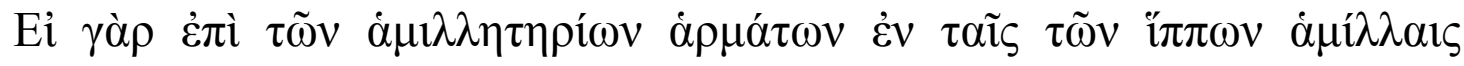

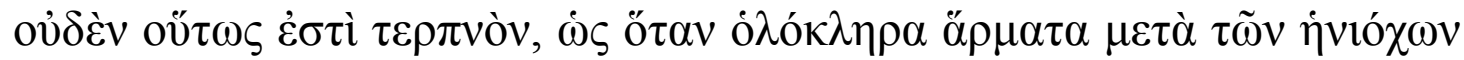

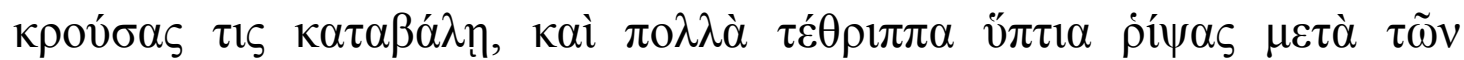

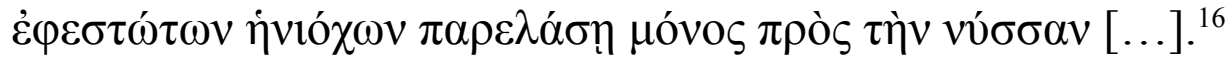

At the end of this part Chrysostom turns to the audience with a question, asking in what order they want him to enumerate the heresies. This is a preface to considerations which will be continued in the next section of the speech, i.e. a rhetorical strategy referred to as the transitus: $:^{17}$

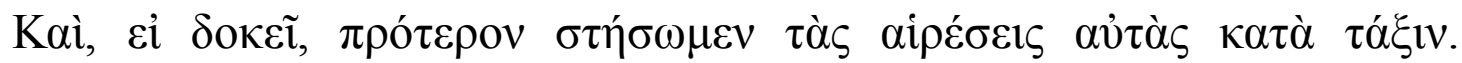

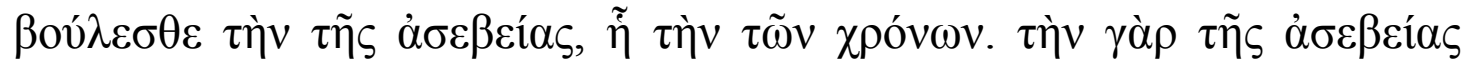

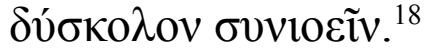

15 PG 62: 218; Allen 2013: 114-116. [Please pay attention and be alert. You see, just as a sharp two-edged sword easily cuts through and destroys even myriad battle lines wherever it falls, because it's sharp on all sides and nothing can withstand its edge - so too, note, do the words of the Spirit].

16 PG 62: 219; Allen 2013: 115. [After all, if in chariot contests and horse races nothing is so entertaining as when someone crashes into all the chariots and their drivers and overturns them, and, throwing on their backs many four-horse chariots and the drivers standing in them, is the only one to reach the finishing post and the end of the race]. $17 \quad$ Lausberg 1998: 159.

18 PG 62: 219; Allen 2013: 117. [And, if you like, let's first make an inventory of the heresies themselves. Do you want to do it in order of their impiety, or their dates? Let's take their dates, because it's difficult to get an overview of their impiety]. 


\subsection{Argumentatio}

The argumentatio is the section of the speech wherein the orator tries to prove the validity of the aforementioned problems. Considering that the homily is intended as an apologia for humility, the argumentatio will be the part where Chrysostom tries to support his thesis using examples of humble attitude. This consequently reveals the effects of adopting such an approach. On the other hand, the orator also wishes to point out the main factors preventing people from attaining the virtue of humility. In accordance with the ancient model, Chrysostom uses argumentation metod referred to as the genus artificiale. ${ }^{19}$ The genus artificiale is found in all kinds of speeches, not necessarily judical in nature. Regarding the evidence needed to support an argument, different types of exempla can be distinguished in the homily. These will be described in the following discussion of individual structures. The most common exempla are res gestae, inductio and auctoritas. ${ }^{20}$ As the generic term, the argumentatio consists of the following parts: the probatio (arguing in favour of one's own position) and the refutatio (pointing out the weakness in the opponent's stance). ${ }^{21}$ In connection to this we note passages in the sermon which aim to support the aptness of its premise as well as those that are meant to show that the arguments of people who reject humility are flawed.

The speaker tries to address three problems. First, he makes reference to the heretics who challenge Jesus Christ's divinity. Arguing against their primary theses, he finally refutes all of them by referring to a higher authority (auctoritas), ${ }^{22}$ in this case the Bible citing lines from the kenosis hymn, a passage in the New Testament which this homily is based on. The structure of this argument is as follows:

\footnotetext{
$19 \quad$ Lausberg 1998: 355-426.

20 Lausberg 1998: 204.

$21 \quad$ Lausberg 1998: 203.

22 Lausberg 1998: 202.
} 
Structure 2 [a]:

a) Refutatio - enumeration of the heretics:

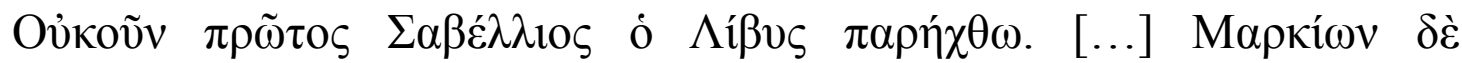

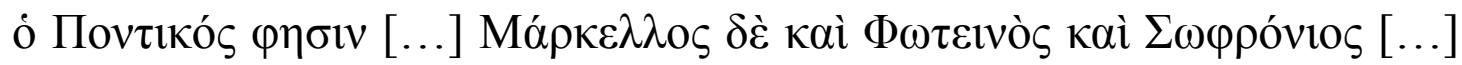

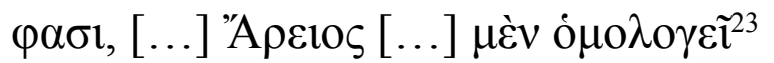

b) Repetition of the race chariot metaphor:

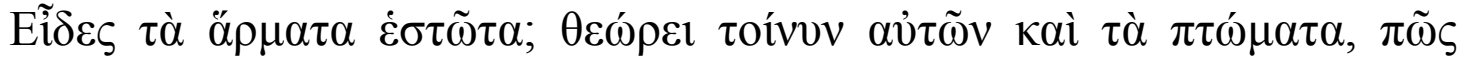

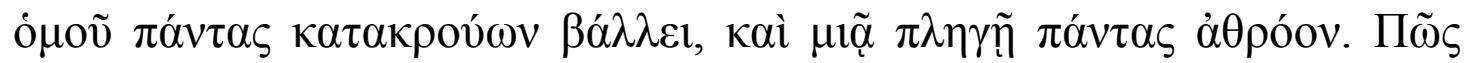
ỡv $\kappa \alpha \tau \alpha \beta \alpha ́ \lambda \lambda \varepsilon \mathrm{l}^{24}$

c) Probatio - examples from the Holy Bible disproving the heretics' stance:

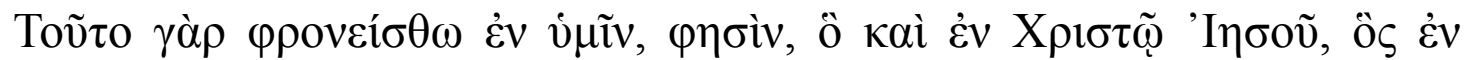

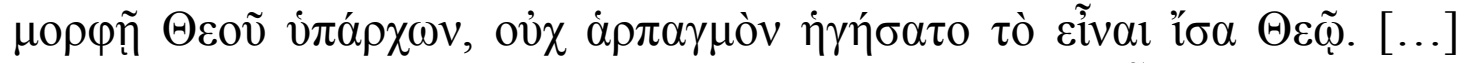

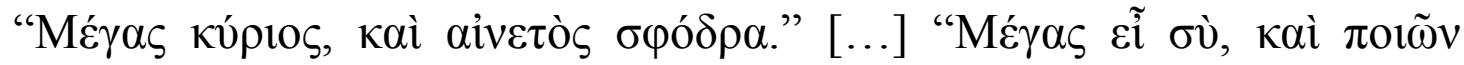

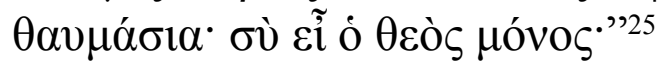

The first point here aims to refute all arguments that could be used against humility of Christ, who is a role model with respect to this virtue. Accepting Jesus' inferiority to God would make any discussion of his humility impossible. Chrysostom claims that if Jesus Christ was not equal to his Father, his humble attitude presented in the kenosis hymn is not an example of humility.

The second issue that the author addresses is the definition of humility. Chrysostom illustrates it with an example from daily life. This kind of exemplification makes the statement more comprehensible to his

$23 \quad$ PG 62: 219; Allen 2013: 117. [Well, let Sabellius the Libyan come forward first. [...] Marcion of Pontus maintains that [...] Marcellus and Photinus and Sophronius maintain that $[\ldots]$ Arius confesses $[\ldots]]$.

24 PG 62: 219; Allen 2013: 117. [Have you seen their chariots standing ready? Look, then, at how they fall, how [the Spirit] crashes into all of them at once and hits them, just with one blow, all at once. How?].

25 PG 62: 219-220; Allen 2013: 117-119. ["Have this mind among yourselves," he says, "which you have in Christ Jesus, who, although he was in the form of God, did not count equality with God a thing to be grasped." [...] "Great is the Lord and exceedingly to be praised" [...] "You are great and do wondrous things. You alone are God"]. 
listeners. The simplicity of thought and attentiveness, which are, according to the Father of the Church, the essence of humility, are demonstrated through contrast with extremely opposite attitudes of specific people. Chrysostom gives the example of a man who is predisposed to thinking about sublime questions juxtaposing him with a simple one. According to him, given that the latter is humble by nature, it is only the former who is capable of practicing humility. Another comparison he draws is that between an emperor and a prefect. Here he argues that only the former has the potential to renounce his superiority and thus show humility. In this way Chrysostom highlights the fact that resignation from that which is beyond one's reach is not a sign of humility. These examples of attitudes based on analogies ground his argumentation in rhetoric and are defined as exempla dissimilia, dissimilar examples. ${ }^{26}$ Following the discussion of humility, Chrysostom returns to the heretics with the aim to defeat them finally. To do this, the speaker uses a metaphor, from the Gospels according to Matthew, Luke and Mark, of the divine seed wielding enough power to heal the land. By uprooting the thorns, i.e. the heretics, the earth will bring abundant fruit. It is important here to emphasize the uncommon cohesion in Chrysostom's reasoning: the speaker takes the problem of heresies on again, referencing his previous permise related to the advocacy of humility. The discussion of the second issue has the following structure:

Structure $2[\mathrm{~b}]$ :

a) Thesis - a definition of humility:

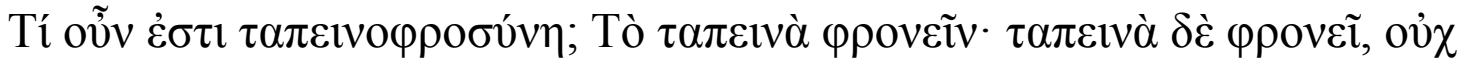

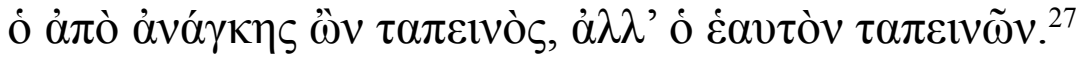

$26 \quad$ Lausberg 1998: 200.

27 PG 62: 221; Allen 2013: 121. [What's humility, then? Thinking humble thoughts. It's not the person who is humble out of necessity who thinks humble thoughts but the person who humbles himself]. 
b) Probatio - examples of humble attitude:

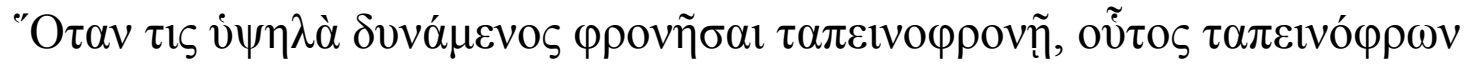

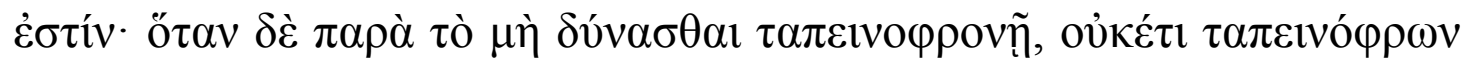
$\dot{\varepsilon} \sigma \tau i ́ v .28$

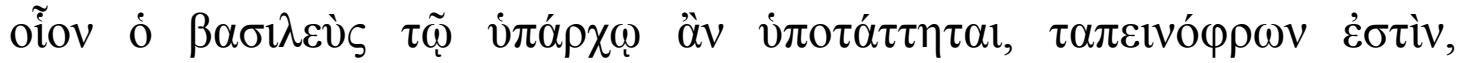

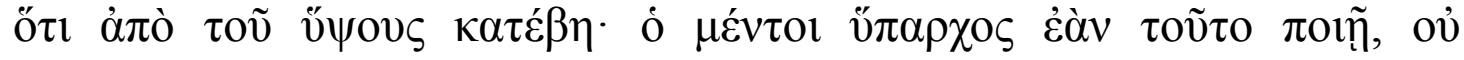
$\tau \alpha \pi \varepsilon 1 v о \varphi \rho о \vee \eta ́ \sigma \varepsilon 1^{29}$

c) Digressio - metaphor of the divine seed from the Bible.

The other part of the homily contains an admonition against the devil, greed and losing faith in God. Chrysostom presents a vision of a man who has rejected God and his doctrine. To support his argument, the preacher refers to a longer excerpt from The Book of Isaiah about a barren vineyard. Again, Chrysostom uses the argumentatio while referring to the Bible. The final part of the homily is a warning against avarice. By reminding us of Judas' story, Chrysostom discusses the destructive consequences of greed. Although Jesus was merciful towards his disciples, Judas betrayed his Master because he craved money. The Church Father focuses on this particular figure. The example raises the listeners' awareness and reveals the hazardous nature of greed. The Father of the Church first presents the story of Judas, who was enslaved by greed; secondly, he warns against being greedy:

\section{Structure $2[\mathrm{c}]$ :}

a) Refutatio - admonition against the Devil, presentation of devilish actions, which hinder the progress towards humility:

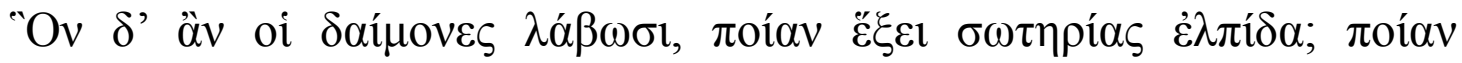

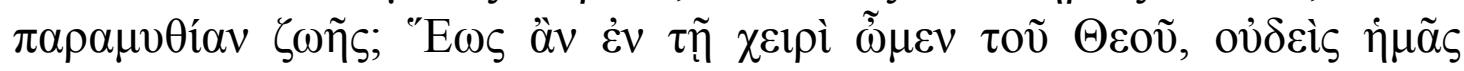

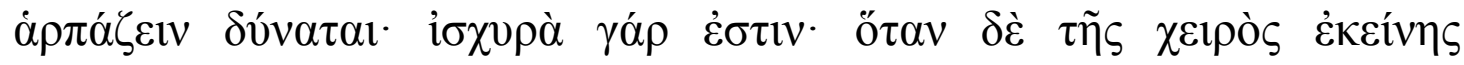

28 PG 62: 221; Allen 2013: 121. [When someone who's capable of lofty thoughts practices humility, they are humble, whereas the person who practices humility beyond their capabilities is no longer humble].

$29 \quad$ PG 62: 221; Allen 2013: 121. [For example, if the emperor subjects himself to a prefect, he's humble because he's descended from a lofty position. However, if the prefect does this, he won't be humble. How could he be? He hasn't humbled himself from a lofty position]. 


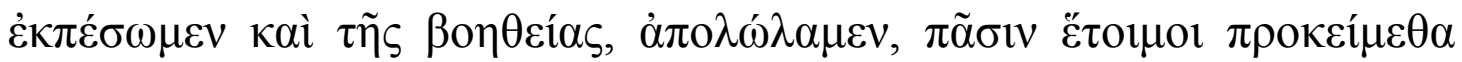

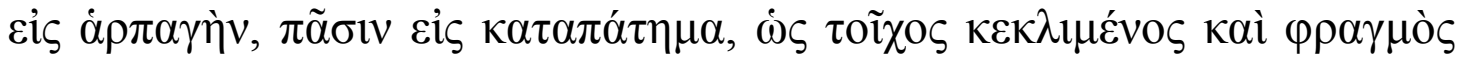

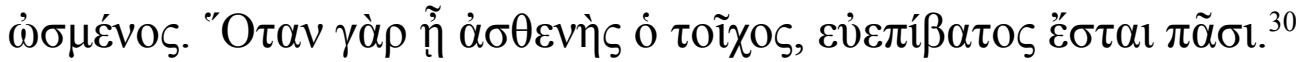

b) Exemplum - the excerpt from The Book of Isaiah (Isa. 5, 1-7) which shows what happened to the man who was possessed by the Devil:

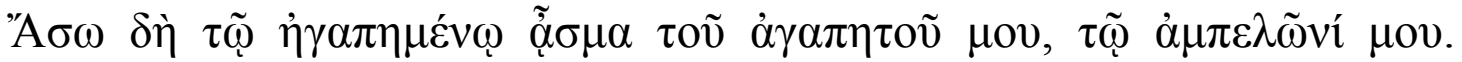

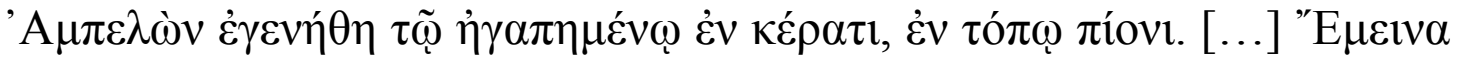

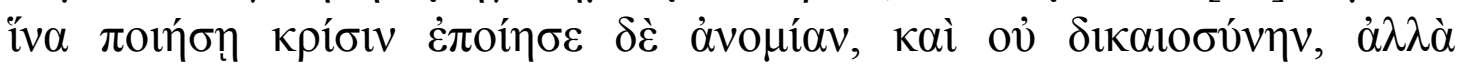
$\kappa \rho \alpha \nu \gamma \eta \dot{v} .^{31}$

c) Refutatio - disastrous consequences of avarice; discussion of the sinfulness of Judas action:

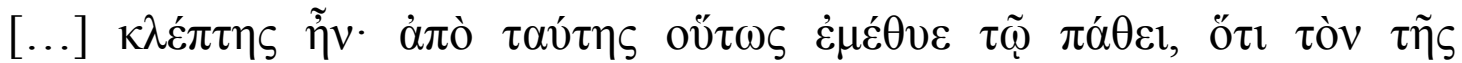

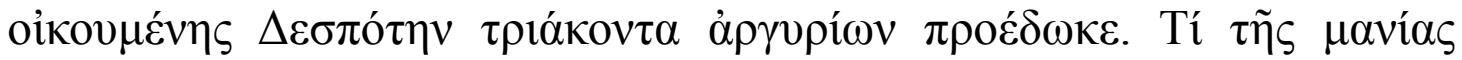

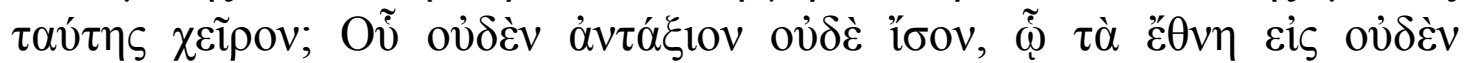

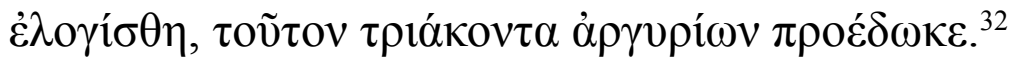

The purpose of this part is to reveal the major impediments to humility and the main factors which prevent its achievment. This is advice as to what should be avoided and what should be done in order to become humble like Christ.

30 PG 62: 223-224; Allen 2013: 127. [What hope of salvation will the one have whom the demons grab? What consolation in life? As long as we are in God's hand, nobody can snatch us away, for the hand is strong. When we fall away from the help of his hand we are lost, we lie ready to be seized by everybody, "like a leaning wall and a tottering fence". When the wall becomes weak, it'll be easy for everyone to break in]. 31 PG 62: 224; Allen 2013: 127-129. [I will sing a song of love to my beloved, concerning my vineyard. My beloved had a vineyard on a hill, in a fertile spot. [...] And I expected that it would make a decision, but it effected injustice, and not righteousness, but a cry].

32 PG 62: 226; Allen 2013: 131. [He was a thief. For thirty pieces of silver he betrayed the Lord. So drunk was he with desire, he betrayed the master of the world for thirty pieces of silver. hat is worse than this madness? The one who has no rival or equal in worth, by whom the nations are accounted as nothing, he betrayed for thirty pieces of silver]. 


\subsection{Peroratio}

The homily concludes with a very brief ending. In pursuance of the ancient criteria, the conclusion is referred to as the peroratio. ${ }^{33}$ According to Aristotle, the ending of a speech should be a brief summary of the arguments mentionedand an elaboration of their significance, i.e. the recapitulatio and it should influence the audience's emotions, a function referred to as the affectus. The reasoning based on the emotions (ratio posita in affectibus) is also divided into two parts: the first one (conquestio) seems to be typical of Chrysostom's homily - the aim is to win the audience's support for one's own position.

In relation to these rules, one must conclude that one of them is not adhered to within the homily, because the ending features no summary of content. ${ }^{34}$ However, an attempt to elaborate the arguments raised is clearly visible. Chrystostom's advice is meant to lead to something of much greater importance, namely the belief in resurrection and the hope of eternal life. Raising that hope is an example of the speaker's impact on the audience's emotions. A eulogy of the Holy Trinity, a typical formula in a homily, can also be seen at the end. This stylistic device has influence on the unity, the sense of togetherness between the speaker and the audience.

\section{Structure [3]:}

a) Presentation of the redemptive qualities of faith; invitation for the listeners to believe in the resurrection of the body:

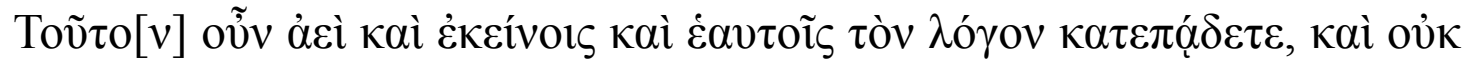

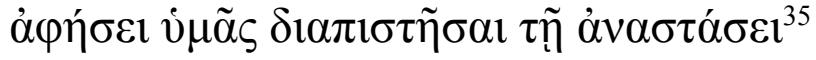

b) Expression of hope; advancing of the thesis that only by faith can man be saved:

\footnotetext{
$33 \quad$ Lausberg 1998: 204-205.

$34 \quad$ Lausberg 1998: 206.

35 PG 62: 228; Allen 2013: 137. [Repeat this constantly both to them and to yourselves, and it won't allow you to disbelieve in the resurrection].
} 


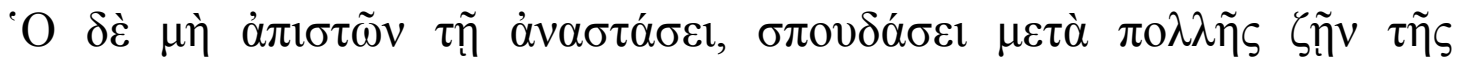

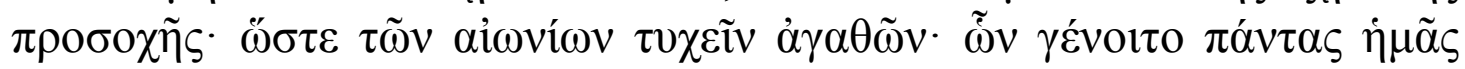
$\dot{\alpha} \xi 1 \omega \theta \tilde{\eta} v \alpha \imath^{36}$

c) Praise to the Holy Trinity - a characteristic ending formula:

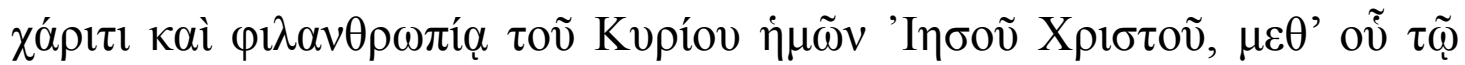

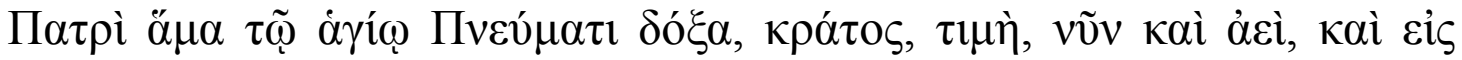

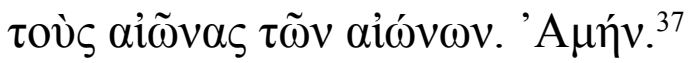

\section{DISPOSITIO}

Dispositio is the ordering of ideas found in the inventio with respect to their utillitas (utility) for one's own party. ${ }^{38}$ The basic function of the dispositio is the division of a whole section, (i.e. of an entire speech as well as of each complete individual part, res as well as verba ${ }^{39}$ ).

Although dispositio is listed as the second phase of treatment following inventio, the temporal relationship between the phrases is not such that they are clearly seperated sequentially; both phases are often inseparably intertwined ${ }^{40}$. Since the dispositio is oriented towards the utilitas, it prevents the chaos of ideas and words; it puts res and verba in order needed to fulfill the utilitarian purposes. ${ }^{41}$

Regarding the fact that the main principle of dispositio is utilitas, it is assisted by principles of order (ordo). In normal circumstances, the ordo naturalis is followed, for instance, by a causa as a whole, especially when the premise is defensible to a sufficient degree. An intensification

\footnotetext{
$36 \quad$ PG 62: 228; Allen 2013: 138. [But the one who doesn't disbelieve in the resurrection will be eager to live their life with much attention in order to obtain the good things of eternity. May we all be judged worthy of this].

$37 \quad$ PG 62: 228; Allen 2013: 138. [by the grace and loving kindness of our Lord Jesus Christ, with whom to the Father together with the Holy Spirit be glory, power, honor, now and always, forever and ever. Amen].

38 Lausberg 1998: 212.

39 Lausberg 1998: 212.

$40 \quad$ Lausberg 1998: 212.

$41 \quad$ Lausberg 1998: 209.
} 
in the expression of completeness is achieved by showing the wealth of features in the central part. ${ }^{42}$ The characteristic form of dispositio which Chrysostom uses in his homily is the five part form of the $1+(1+1+1)+1$ type, based on enumeration using the five fingers of the hand. The tripartite division of the middle is then taken to constitute a separate whole.

$$
\begin{aligned}
\text { Dispositio: } & \text { Inventio: } \\
1-\text { introduction } & \text { exordium/narratio } \\
1+1+1 \text { the central part } & \text { argumentatio (three issues) } \\
1-\text { ending } & \text { peroratio }
\end{aligned}
$$

$* * *$

Taking into account the main goal of Chrysostom's work, his homily belongs to the category of deliberative speeches, and all elements may be identified in it which are characteristic of such a speech. The text is organized into a system which reveals a five-part structure. The homily is therefore a model rhetorical construct, which makes it easier for the listeners to understand every part of the content. Regarding the individual parts, they include some features typical of them only, but in some the parts overlap and there is no clear-cut boundary betwen them. One could interpret this fact as a sign of defects in Saint John's rhetoric, but it might as well indicate that his choice and use of rhetorical strategies was a conscious decision and that he did not follow the traditional guidelines blindly. The Church Father relies on them only as long as he considers them useful at a given point. In order to come to general conclusions concering the intentional usage of rhetorical figures and structures by Chrysostom, it seems necessary to subject his other homilies to this kind of analysis. This will facilitate comparison of individual homilies with a view to identifying their distinctive features, which will open future research opportunitieswith respect to John Chrysostom's homilies.

$42 \quad$ Lausberg 1998: 214. 


\section{BIBLIOGRAPHY}

\section{Primary sources:}

Allen P., 2013, John Chrysostom, Homilies on Paul's Letter to the Philippians, Atlanta, pp. 113-169.

Bareille J. A., 1872, Euvres complètes de Saint Jean Chrysostome: Traduction nouvelle, Paris, pp. 435-597 (in Vol. 18) and pp. 1-23 (in Vol. 19).

Cotton C. W., 1843, The Homilies of S. John Chrysostom, Archbishop of Constantinople, on the Epistles of St. Paul the Apostle to the Philippians, Colossians, and Thessalonians, Oxford, pp. 87-135.

Migne P., 1862, Patrologiae Graecae Tomus LXII. S. Joannes Chrysostomus. Patrologiae cursus completus, Paris, pp. 218-228.

Stoderl W., 1924, Des hl. Kirchenlehrers Johannes Chrysostomus, Erzbischofs von Konstantinopel, Kommentar zu den Briefen des hl. Paulus an die Philipper und Kolosser, Munich, pp. 5-23.

\section{Secondary sources:}

Allen P., Neil B., Mayer W., 2009, Preaching Poverty in Late Antiquity: Perceptions and Realities, Leipzig.

Allen P., Mayer W., 1994, 'Chrysostom and the Preaching of Homilies in Series: A New Approach to the Twelve Homilies In epistulam ad Colossenses (CPG 4433)', Orientalia Christiana Periodica 60, pp. 274-275.

Allen P., Mayer W., 1995, 'Chrysostom and the Preaching of Homilies in Series: A Re-Examination of the Fifteen Homilies in Epistulam ad Philippenses (CPG 4432)', Vigiliae Christianae 49/3, pp. 270-289.

Amirav H., 2004, 'The Rhetorical Expression of Exegesis: The Case of John Chrysostom', [in:] Giovanni Crisostomo: Oriente e Occidente tra IV e V secolo, Roma.

Baur Ch., 1959-1960, John Chrysostom and His Time, Westminster.

Cunningham C. B., Allen P. (eds.), 1998, Preacher and Audience: Studies in Early Christian and Byzantine Homiletics. A New History of the Sermon, Leiden.

Illert M., 2000, Johannes Chrysostomus und das antiochenisch-syrische Mönchtum: Studien zu Theologie, Rhetorik und Kirchenpolitik im antiochenischen Schriftum des Johannes Chrysostomus, Zürich.

Kelly J. N. D., 1995, Golden Mouth: The Story of John Chrysostom - Ascetic, Preacher, Bishop, London.

Lampe G. W. H., 1969, A Patristic Greek Lexicon, Oxford. 
Lausberg H., 1998, Handbook of Literary Rhetoric, Leiden-Boston-Köln.

Liddell H. G., Scott R., Jones H. J., 1968, A Greek-English Lexicon, Oxford.

Mayer W., Allen P., 2000, John Chrysostom. The Early Church Fathers, London.

Mitchell M. M., 2002, The Heavenly Trumpet: John Chrysostom and the Art of Pauline Interpretation, Louisville.

Quasten J., 1960, The Golden Age of Greek Patristic Literature from the Council of Nicea to the Council of Chalcedon, Utrecht-Antwerp. 